\title{
References:
}

1. Bezrukov, A. (2020). Transformation and interpretation of gender concepts in metaphysical dimension: From contemplative worldview to transpersonal experience. Humanities \& Social Sciences Reviews, 8(4), 373-381. https://doi.org/10.18510/hssr.2020.8437.

2. Grady, H. (2017). John Donne and Baroque allegory: The aesthetics of fragmentation. Cambridge University Press. https://doi.org/10.1017/ 9781108164337.

3. Locke, J. D. (2018). Images and image symbolism in metaphysical poetry with special reference to other-worldliness. Van Duuren Media.

4. Metaphysical conceit: Element of metaphysical poetry. (2016, December 25). Moelancholy. https://moelancholy.wordpress.com/2016/ 12/25/metaphysical-conceit.

5. Smith, A. J. (1992). Metaphysical wit. Cambridge University Press. https://doi.org/10.1017/CBO9780511553394

DOI https://doi.org/10.30525/978-9934-26-039-1-19

\section{ЖАНРОВЫЕ УСЛОВИЯ ВОСПРИЯТИЯ ВЕРТИКАЛЬНОГО КОНТЕКСТА (ШРИФТ)}

\author{
Дудников Н. А. \\ кандидат филологических наук, доцент, \\ доиент кафедри перевода и славянской филологии \\ Криворожского государственного педагогического университета \\ 2. Кривой Рог, Днепропетровская область, Украина
}

Мохначева О. В.

кандидат филологических наук, доиент, доцент кафедри перевода и славянской филологии Криворожского державного педагогічного университета г. Кривой Рог, Днепропетровская область, Украина

В современной литературоведческой ситуации все большее значение приобретает понятие «текст» как основной предмет исследования, а также связанные с ним парадигмы «контекст», «паратекст», «гипертекст» и пр. Интерес к функциям этих элементов художественного произведения обусловлен активной разработкой ключевой категории эстетики постмодернизма «мир как текст» (Ж. Деррида) и во многом 76 
подкреплен концепцией открытого текста, в основе которой лежит тезис Ж. Дерриды о разрушение оппозиции «текст-контекст». Вытекающая отсюда идея бесконечного или «тотального» текста позволяет предположить, что контекст (как «горизонтальный», выводимый непосредственно из текста, так и «вертикальный», предполагаемый) может составлять основное информативное и смысловое содержание литературного текста за его знаковыми пределами.

Понятие «вертикального контекста», созвучное идее Р. Барта о «вертикальном и горизонтальном типах чтения», обосновано и разработано О.С. Ахмановой, И. В. Гюббенет, Н. Катинене, ЈІ.В. Болдыревой и др. Под ним понимается объективно заложенная в художественном произведении информация историко-филологического плана: экономические, социальные, культурные и географические сведения (социально-исторический вертикальный контекст), а также цитаты, литературные, культурные и национальные аллюзии (филологический вертикальный контекст) [1;5].

Проблема жанра в современном литературоведении - одна из наиболее неопределенных. Рассматривая текст в качестве «объяснительной системы», теоретики постмодернизма понимают жанр как «литературный дискурс», пытающийся упорядочить реальность, или как «хорошо рассказанную историю», способную отображать реальность с привлечением любых средств. В результате, игровая и метаповествовательная природа текста способствует размыванию границ и самого текста, и расплывчатости его жанровых критериев, что выражается в синкретичности современного романа (через «коллаж», «монтаж», «инбридинг» (Н. Т. Пасхарьян [6 ,с.9]), «циклизацию» и пр.). При этом жанровые признаки проявляются как в тексте в целом, так и в отдельных фрагментах, включенных в него. В зависимости от жанровых условий вертикальный контекст может по-разному определять закодированное смысловое содержание текста.

Примером может послужить роман У.Эко «Баудолино», который внешне демонстрирует жанровые характеристики исторического романа в сочетании с «хрониками, mirabilia и рыцарским романом» (О. Ю. Муштанова [7]), детективом, авантюрным и романом-биографией. Ярчайший образец постмодернистского жанрового симбиоза, роман «Баудолино» имеет широкий вертикальный контекст, как социальноисторический (в частности, когда речь идет о Средневековье и реставрации деяний Фридриха Барбароссы), так и филологический - во второй половине текста, когда путешествие Баудолино и его друзей заметно переносится в литературно-художественное пространство, 
обрастает суевериями, средневековыми ересями, книжными проектами (например, Гуингмы и одноногие исхиаподы; звери-фантомы химера и мантихора; «бессветная провинция» Абхазия и государствоутопия Пресвитера Иоанна). В соответствии с жанровым характером историографического метаромана, каковым в рамках постмодернистских характеристик и является этот текст, вертикальный контекст переводит смысловые акценты в плоскость воссоздания «красивой лжи»: «Мы ищем не сам предмет, а тех, кто говорит о предмете». По сути, это роман о преодолении невежества, о путях освоения пространства, воссозданного в слове; не только географического, но и того воображаемого пространства, которое существует благодаря искусству рассказывания, передается как богатый смыслами текст и опирается на ассоциативные ряды других текстов.

В романе Э. Берджесса «Заводной апельсин» образцом включения вертикального контекста может служить множественная отсылка к музыкальным пристрастиям персонажа, которые без оглядки на жанровые условия текста могут быть восприняты как характеристики его эстетической утонченности или тяги к прекрасному. Однако особенности антиутопии с ее конфликтной основой, с жестким противопоставлением личной свободы и общественного давления, к которой по жанровым признакам ближе всего этот роман, позволяют выявить в конфликте «личность-система» значение «произвол-порядок», и далее противопоставление «добро-зло» и отсылают к философии А. Шопенгауэра об интуиции как единственном способе познания Мировой Воли и о ведущей роли музыки, которая единственная высвобождает сущность личности: в Алексе она высвобождает зверя, который хочет «терзать и курочить»: «Под звуки И. С. Баха я стал гораздо лучше ponimatt, что это название значит; коричневая, охряная роскошь аккордов старого мастера раскрыла мне глаза на то, что мне бы следовало их обоих toltshoknutt куда серьезней, разорвать их на части и растоптать в пыль на полу их же собственного дома» [Б, с. 16].

Как видим, жанровая специфика текста корректирует его восприятие и, акцентируя внимание на фоновые знания (в данном случае, на литературоведческую грамотность), активирует те закодированные смысловые уровни, которые высвечивает вертикальный контекст («контекст культуры», «контекст литературных произведений и контекст произведений других видов искусства» [Цит.по:4, с.11]). Вертикальный контекст, соотнесенный с жанровой природой произведения, обогащает спектр смысловых глубин текста и способствует его адекватному пониманию. 


\section{Литература:}

1. Ахманова О. С., Гюббенет И. В. «Вертикальный контекст» как филологическая проблема. Вопросы языкознания. 1977. № 3. С. 47-54.

2. Берджесс Э. Заводной апельсин / пер. с англ. В. Б. Бошняк. Москва: АСТ, Астрель, 2010. 224 с.

3. Болдырева Л. В. Социально-исторический вертикальный контекст (на материале английской художественной литературы): монография. Москва: Диалог-МГУ, 1997. 88 с.

4. Геращенко А.М. Интертекстуальность и вертикальный контекст (на примере английской литературы). Проблемы общей и частной теории текста: сборник научных статей. Бийск: БПГУ им. В.М. Шукшина, 2008. C. $10-15$.

5. Гюббенет И. В. Основы филологической интерпретации литературно-художественного текста. Москва: Издательство МГУ, 1991. $205 \mathrm{c}$.

6. Метаморфозы жанра в современной литературе: Сборник научных трудов / Редакторы-составители: Пахсарьян Н. Т., Ревякина А.А. Москва, 2015. 386 с. URL: http://inion.ru/site/assets/files/2558/2015_snt_ metamorfozy_zhanra.pdf Дата обращения 5.02.2021.

7. Муштанова О.Ю. Интерпретации исторических фактов в итальянской литературе на примере романа Умберто Эко «Баудолино». Вестник МГИМО-Университета. 2015.1(40). С. 268-273. URL: https:// cyberleninka.ru/article/n/interpretatsii-istoricheskih-faktov-v-italyanskoyliterature-na-primere-ro Дата обращения 12.01.2021 